Research article Open Access

\title{
Expression patterns and prognostic value of Bag-1 and Bcl-2 in breast cancer
}

\author{
Yasmine Nadler ${ }^{1}$, Robert L Camp², Jennifer M Giltnane², Christopher Moeder², David L Rimm², \\ Harriet M Kluger ${ }^{1}$ and Yuval Kluger ${ }^{3}$
}

\author{
1Department of Medicine, Yale University School of Medicine, New Haven, CT 06520, USA \\ ${ }^{2}$ Department of Pathology, Yale University School of Medicine, New Haven, CT 06520, USA \\ ${ }^{3}$ Department of Cell Biology, New York University School of Medicine, 540 First Avenue, 3rd Floor, New York, NY 10016, USA \\ Corresponding author: Yuval Kluger, yuval.kluger@med.nyu.edu
}

Received: 7 Nov 2007 Revisions requested: 22 Jan 2008 Revisions received: 14 Apr 2008 Accepted: 23 Apr 2008 Published: 23 Apr 2008

Breast Cancer Research 2008, 10:R35 (doi:10.1186/bcr1998)

This article is online at: http://breast-cancer-research.com/content/10/2/R35

(C) 2008 Nadler et al.; licensee BioMed Central Ltd.

This is an open access article distributed under the terms of the Creative Commons Attribution License (http://creativecommons.org/licenses/by/2.0), which permits unrestricted use, distribution, and reproduction in any medium, provided the original work is properly cited.

\begin{abstract}
Introduction Bcl-2 antanogene-1 (Bag-1) binds the antiapoptotic mediator Bcl-2, and enhances its activity. Bcl-2 and Bag-1 are associated with chemotherapy resistance in cancer cells. Drugs that target $\mathrm{Bcl}-2$ are currently in clinical development. The purpose of the present study was to examine expression patterns of Bag-1 in a large cohort of breast tumors and to assess the association with $\mathrm{Bcl}-2$, estrogen receptor, progesterone receptor and Her2/neu, and other clinical/ pathological variables.

Methods Tissue microarrays containing primary specimens from 638 patients with 10-year follow-up were employed, and the expression of Bag-1, Bcl-2, estrogen receptor, progesterone receptor and Her2/neu was assessed using our automated quantitative analysis method. We used cytokeratin to define pixels as breast cancer (tumor mask) within the array spot, and we measured biomarker expression within the mask using Cy5 conjugated antibodies.
\end{abstract}

Results High Bcl-2 expression was associated with improved survival in the entire cohort and in the node-positive subset $(P=$ 0.008 and $P=0.002$, respectively). High Bag-1 expression was associated with improved survival in the node-positive subset $(P$ $=0.006$ ). On multivariable analysis, neither Bcl-2 nor Bag-1 retained their independence as prognostic markers. Strong associations were found between Bag-1, Bcl-2, estrogen receptor and progesterone receptor.

Conclusion Bag-1 and Bcl-2 expression in breast tumors is associated with improved outcome and steroid receptor positivity. Evaluation of Bcl-2 and Bag-1 expression in breast cancer may identify a subset of patients with a favorable prognosis, who might not benefit from chemotherapy or who might benefit from $\mathrm{Bcl}-2$ targeting agents in addition to antihormonal therapy.

\section{Introduction}

Breast cancer is the most common malignancy among women, with a projected incidence of 178,480 new diagnoses in the United States in 2007 [1]. Over 40,000 women are expected to die from metastatic disease in 2007 [1]; adjuvant systemic therapy is therefore given for early-stage disease to decrease the risk of death from breast cancer.

A number of factors are used to assess the risk of developing metastatic disease and death, including lymph node involvement, tumor size, nuclear and histologic grade, age, hormone receptor expression and Her2/neu status. Lymph node involvement is the most reliable predictor of metastatic relapse, yet within the lymph node-positive subset and the lymph node-negative subset of patients there is variability in prognosis, and we have no reliable means of determining which patients will survive without adjuvant systemic therapy. For example, it is well established that adjuvant chemotherapy decreases the risk of recurrence in node-positive patients [2], yet older studies showed that there is a subset of node-positive breast cancer patients, particularly those with estrogen receptor (ER)-positive tumors, who survive with tamoxifen alone [3]. There is therefore great need to identify new prognostic markers that will assist in patient selection for adjuvant

$\overline{\mathrm{AQUA}}=$ automated quantitative analysis; Bag-1 = Bcl-2 antanogene-1; ER = estrogen receptor; PR = progesterone receptor. 
therapies. Moreover, these markers can assist in selection of biospecific therapies once drugs that target these markers become available.

A number of prior studies have assessed the prognostic value of the anti-apoptotic mediator Bcl-2 in breast cancer [4-24]. $\mathrm{Bcl}-2$ blocks apoptosis via the mitochondrial pathway by inhibiting the release of cytochrome $\mathrm{C}$ from the mitochondria, thus preventing the cascade of events that results in compromise of the mitochondrial outer membrane potential, which in turn leads to caspase- 9 activation and subsequent apoptosis [25].

Bcl-2 has been shown to inhibit chemotherapy-induced apoptosis, and chemotherapy resistance has been reversed in cancer cells treated with Bcl-2-targeting therapy [26]. Although $\mathrm{Bcl}-2$ is an anti-apoptotic protein, high Bcl-2 expression has been observed in ER-positive breast cancers $[4,8,13,14,18,20,23,27-38]$, as well as in progesterone receptor (PR)-positive breast cancers [4,13,14,27-31,33-39], and has been associated with improved survival in breast cancer $[4-24,40]$. The largest of these studies - conducted by Callagy and colleagues - included 930 cases, and showed that positive $\mathrm{Bcl}-2$ expression was a strong predictor of improved survival, independent of the Nottingham prognostic index [6]. High Bcl-2 expression has been associated with improved prognosis even among patients at very high risk for distant relapse, with over 10 involved lymph nodes [41].

Bcl-2 antanogene-1 (Bag-1) is a protein that has multiple cellular functions. Bag-1 binds to Bcl-2 and enhances its antiapoptotic activity [42,43]. Bag-1 also has anti-apoptotic effects that are independent of Bcl-2; it binds to multiple receptor tyrosine kinases and enhances their ability to inhibit apoptosis [44], and it interacts with the heat shock proteins HSC70 and HSP70 [45]. Bag-1 modulates the function of the $E R$, and enhances estrogen-dependent transcription [46]. By binding to its partners and regulating their function, Bag-1 therefore modulates pathways necessary for transcription and cell growth and survival, as reviewed by Townsend and colleagues [47].

The Bag-1 gene has four protein isoforms, three major isoforms (p50, p46 and p33 - Bag-1L, Bag-1M and Bag-1S, respectively) and one minor isoform (p29) $[48,49]$. The isoforms arise from a single mRNA by alternative translation initiation [50,51]. The distinct isoforms are associated with different subcellular locations and have variable functions $[49,52]$. Bag- $1 \mathrm{~L}$ is localized to the nucleus, whereas Bag-1M and Bag-1S are generally found in the cytoplasm. In some cell types and in conditions of stress, however, Bag-1M may also be localized to the nucleus $[49,52]$.

Several preclinical studies have demonstrated the importance of Bag-1 in breast cancer [19,42,53-60]. In breast cancer cell lines, Bag-1 prevents cells from undergoing apoptosis and protects cells from other forms of stress, including radiation, chemotherapy and hypoxia [61]. ZR-75-1 breast cancer cells stably transfected with Bag-1 have increased survival in culture, and form larger tumors than nontransfected cells when injected into mammary fat pads of mice [62]. ZR-75-1 cells stably expressing mutated forms of Bag-1 display retarded growth in vivo and in vitro [62], suggesting that targeting Bag1 might be a useful strategy for treating breast cancer.

A number of relatively small cohort studies have assessed expression of Bag-1 in breast cancer [19,42,52-60,63], with divergent results. For example, Tang and colleagues studied 140 breast tumors and found an association between high nuclear Bag-1 expression and decreased survival [58], Townsend and colleagues found no significant association between nuclear or cytoplasmic Bag-1 and survival in 160 patients [59], and Turner and colleagues found a strong association between high cytoplasmic Bag-1 and improved survival [60].

Similarly, reported associations between Bag-1 and Bcl-2, ER and $\mathrm{PR}$ are variable; some researchers have reported positive correlations between Bag-1 and Bcl-2 expression [56,57,60], while other workers have made the opposite observation [42,52]. Some studies have shown no association between Bag-1 expression and ER or PR expression [58-60], whereas other studies have shown that Bag-1 and ER do tend to coexpress $[46,52,57]$, as do Bag-1 and PR $[46,57]$. These inconsistencies could be due to relatively small cohorts, technical variability in staining from specimen to specimen, and lack of quantitative measures for immunohistochemistry.

To address these issues, we assessed expression of Bag-1 on a large cohort of primary breast cancers using tissue microarrays, employing a new method of automated, quantitative analysis. This method has been shown to be more accurate than pathologist-based scoring of 3,3'-Diaminobenzidine Tetrahydrochloride stain (DAB) stain [64], and produces quantitative measures that are directly proportional to the concentration of the measured biomarker $[65,66]$. Since the ER, PR, Her2/neu and $\mathrm{Bcl}-2$ have prognostic importance in breast cancer and are also targets of drugs that are in clinical use, we also assessed the association between Bag-1 expression and these markers, with the goal of characterizing subsets of patients based on expression of these biomarkers. We found that Bag-1 and Bcl-2 tend to be coexpressed, and expression is correlated with ER and PR expression. Both Bag-1 and Bcl2 were associated with improved survival among node-positive breast cancer patients, particularly those with hormone receptor-positive tumors.

\section{Materials and methods Cell lines and western blots}

The MDA-MB-468, MCF-7, T47D, BT-474 and SKBR3 (human breast cancer) cell lines were purchased from ATCC 
(Manassas, VA, USA). Western blotting of protein extracts was performed using standard methods. Bag-1 and Bcl-2 expression were detected by overnight incubation with mouse anti-Bag-1 lgG (Chemicon, Temecula, CA, USA) at 1:400 and with mouse anti-Bcl-2 IgG (Dako Corp., Carpinteria, CA, USA) at 1:6,000. Protein loading was assessed using rabbit anti- $\beta$ actin (Sigma-Aldrich, St Louis, MO, USA) at 1:5,000.

\section{Tissue microarray construction}

The breast cancer tissue microarrays were constructed as previously described [67]. A total of 319 node-negative and 319 node-positive breast cancer cores, each measuring 0.6 $\mathrm{mm}$ in diameter, were spaced $0.8 \mathrm{~mm}$ apart on two glass slides. The cohort was constructed from paraffin-embedded, formalin-fixed tissue blocks obtained from the Yale University Department of Pathology Archives. Specimens and clinical information were collected under the guidelines and approval of a Yale University Institutional Review Board.

By standard immunohistochemistry, ER staining was positive in 52\%, PR in $46 \%$ and HER2/neu in $14 \%$ of specimens. Nuclear grade 3 (on a 1 to 3 scale) was seen in $28 \%$ of the specimens, and $59 \%$ were larger than $2 \mathrm{~cm}$. The histological subtypes included $72 \%$ invasive ductal carcinoma and $1 \%$ lobular carcinoma, and $14 \%$ had mixed or other histology. The specimens were resected between 1962 and 1983, with a follow-up range between 4 months and 53 years, and a mean follow-up time of 12.6 years. Patient age at diagnosis ranged from 24 to 88 years (mean age, 58 years).

A complete treatment history was not available for the entire cohort. Most patients were treated with local irradiation. None of the node-negative patients were given adjuvant systemic therapy. A minority of the node-positive patients (approximately $15 \%$ ) received chemotherapy, and approximately $5.6 \%$ of patients received tamoxifen (postmenopausal patients with ER-positive tumors, treated after 1978). The time between tumor resection and tissue fixation was not available.

A pathologist reviewed slides from all of the blocks to select representative areas of invasive tumor to be cored. The cores were placed on the tissue microarray using a Tissue Microarrayer (Beecher Instruments, Silver Spring, MD, USA). The tissue microarrays were then cut into $0.5 \mu \mathrm{m}$ sections and were placed on glass slides using an adhesive tape-transfer system (Instrumedics, Inc., Hackensack, NJ, USA) with UV cross-linking.

\section{Immunohistochemistry}

Staining was performed for automated analysis of breast cancer specimens as previously described [68]. Briefly, slides were deparaffinized in xylene, and were transferred through two changes of $100 \%$ ethanol. For antigen retrieval, the slides were pressure-cooked in $6.5 \mathrm{mM}$ sodium citrate $(\mathrm{pH} \mathrm{6.0)}$. Endogenous peroxidase activity was blocked in a mixture of methanol and $2.5 \%$ hydrogen peroxide for 30 minutes. To reduce nonspecific background staining, slides were incubated for 30 minutes in $0.3 \%$ bovine serum albumin $/ 1 \times$ Trisbuffered saline.

Slides were then incubated at $4^{\circ} \mathrm{C}$ overnight with the following primary antibodies: mouse monoclonal anti-Bcl-2 (clone 124; Dako) at 1:40; mouse monoclonal anti-Bag-1 (MAB4611; Chemicon) at 1:150; mouse monoclonal anti-ER (Dako) at 1:50; mouse monoclonal anti-PR at 1:50 (Dako); and rabbit anti-Her2/neu at 1:8,000 (Dako). All antibodies were diluted in Tris-buffered saline containing $0.3 \%$ bovine serum albumin. Goat anti-mouse (or anti-rabbit for Her2/neu) horseradish peroxidase-decorated polymer backbone (Envision; Dako) was used as a secondary reagent, and Cy5-tyramide (Perkin Elmer Life Science, Waltham, MA, USA) was used to visualize the target.

To create a tumor mask, primary slides were simultaneously incubated with rabbit anti-human cytokeratin antibodies diluted at 1:200. For Bcl-2, Bag-1, ER and PR, rabbit anticytokeratin was used. Mouse anti-cytokeratin was used for $\mathrm{Her} 2 / \mathrm{neu}$. The anti-cytokeratin antibodies were visualized with secondary Alexa 488-conjugated goat anti-rabbit or goat antimouse antibodies (Molecular Probes, Inc., Eugene, OR, USA). Coverslips were mounted with ProLong Gold antifade reagent with 4',6-diamidino-2-phenylindole (Invitrogen Corp, Grand Island, NY, USA).

\section{Automated image acquisition}

Images were acquired using automated quantitative analysis (AQUA), as described previously [67]. Briefly, areas of tumor were distinguished from stroma by creating a mask with the cytokeratin signal tagged with Alexa 488. Coalescence of cytokeratin at the cell surface was used to identify the membrane/cytoplasm compartment within the tumor mask, while 4',6-diamidino-2-phenylindole (DAPI) was used to identify the nuclear compartment within the tumor mask. The target markers, Bag-1, Bcl-2, ER, PR or Her2/neu, were visualized with Cy5 (red). Multiple monochromatic, high-resolution $(1,024 \times$ $1,024$ pixels, $0.5 \mu \mathrm{m})$ grayscale images were obtained for each histospot, using the $10 \times$ objective of an Olympus AX-51 epifluorescence microscope (Olympus, Melville, NY, USA) with an automated microscope stage and digital image-acquisition driven by custom program and macro-based interfaces with IPLabs software (Scanalytics Inc., Fairfax, VA, USA).

\section{Algorithmic image analysis}

Images were analyzed using algorithms that have been previously extensively described [68]. Two images (one in-focus and one out-of-focus) were taken of the compartment-specific tags and the target marker. A percentage of the out-of-focus image was subtracted from the in-focus image for each pixel, representing the signal-to-noise ratio of the image. An algorithm called the Rapid Exponential Subtraction Algorithm was 
used to subtract the out-of-focus information in a uniform fashion for the entire microarray. Subsequently, a second algorithm called the Pixel Locale Assignment for Compartmentalization of Expression algorithm was used to assign each pixel in the image to a specific subcellular compartment, and the signal in each location was calculated. The data were expressed as the average signal intensity per unit of compartment area on a scale of 0 to 255, and were expressed as target signal intensity relative to the compartment area.

\section{Statistical analysis}

The JMP5 software package (SAS Institute Inc., Cary, NC, USA) was used for data analysis. Continuous AQUA scores of target expression were dichotomized by the median score, and associations with clinical and pathological parameters were completed using unpaired $t$ tests. The prognostic significance of the parameters was assessed using the Cox proportional hazards model with breast cancer-specific survival as an endpoint. Survival curves were generated using the Kaplan-Meier method, with significance evaluated using the Mantel-Cox long-rank test. Associations between continuous AQUA scores for the different markers were assessed by the Spearman's rho test.

To generate the principal component analysis biplot (presented in Figure 1), we tabulated our dataset in a matrix consisting of 439 patients (rows) and five biomarkers (columns). We only included the 439 patients (out of 638 patients) who had values for all five biomarkers. The first step in this analysis involves data preprocessing obtained by first normalizing each marker 439-dimensional profile by its median value, followed by a two-way data-centering procedure of this normalized data matrix. The centering procedure involves transforming each entry of this matrix by subtraction of the row and column means of this entry and addition of the overall matrix mean, leading to a transformed matrix having all row sums and all column sums equal to zero. Reduction in the number of variables is useful for visualizing how the patient population is distributed in the five-dimensional variable space. Principal component analysis is an unsupervised dimension reduction method that generates a new set of decorrelated variables (principal components) as linear combinations of the original variables (biomarkers). The majority of the variation associated with the Her2/neu, ER, PR, Bcl-2 and Bag-1 variables can be captured by the most dominant principal components. An additional advantage of expressing the data in terms of the leading principal components is their robustness to noise.

The projections of the samples onto the leading principal components were computed by applying the singular value decomposition to the data matrix (after preprocessing as described above and in previous works [69]). We used principal component biplots to display the biomarkers (columns of the data matrix) and the patients (rows of the data matrix) simultaneously as points in a two-dimensional space [70]. The biplot provides an optimal approximation of the data matrix by

\section{Figure 1}

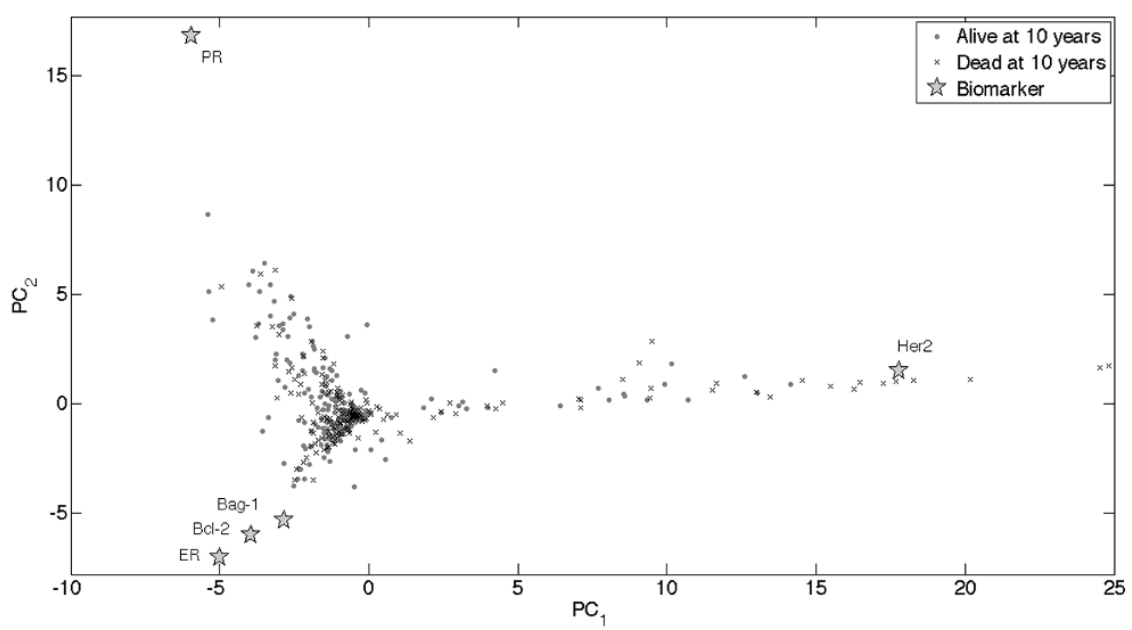

Principal component analysis and biplot. Projection of five-dimensional patient biomarker profiles with no missing data (439 instances) and the 439-dimensional biomarkers profiles onto the two leading principal components of a matrix consisting of expression profiles of Her2/neu, estrogen receptor (ER), progesterone receptor (PR), Bcl-2 and Bcl-2 antanogene-1 (Bag-1) present in all 439 samples. Each patient is represented by a distinct symbol $(\cdot$, alive at 10 years; $\times$, dead at 10 years). The accumulated variation captured by the first and second principal components is $92 \%$ of

the total variation. Overlaying a two-dimensional scatter plot representing the projection of the biomarkers ( $\vec{w}$ ) onto the first and second principal components on top of the two-dimensional patient scatter plot representing the projection of their five-dimensional biomarker profiles onto the two leading principal components forms a biplot. The biplot can be used to read the approximated transformed expression levels. 
such a two-dimensional structure, in that it displays the singular value decomposition - which gives the rank-two approximation to the data matrix having the smallest mean-squared error. The expression of a given biomarker in a given patient sample is approximated by the projection of the biomarker vector onto the direction of the patient sample vector, multiplied by the length of the patient sample vector. In the present ranktwo approximation, therefore, for a given biomarker and for patient vectors of a given length, the biomarker is expressed at a higher (or lower) level in patients whose vector points in nearly the same (or opposite) direction as the biomarker. A biomarker is not overexpressed or underexpressed for patients whose vector is orthogonal to the biomarker vector, and is underexpressed for patients whose vector form an obtuse angle with the biomarker vector.

\section{Results}

\section{Western blots for Bag-1 and Bcl-2}

Western blot analysis for Bag-1 showed bands at $36 \mathrm{kDa}, 46$ $\mathrm{kDa}$ and $50 \mathrm{kDa}$ (Figure 2). These represent the three isoforms reported in the literature [49], and all three isoforms are recognized by the antibody. The strongest expression of Bag-1 was observed in BT-474, consistent with findings by other researchers [42]. For $\mathrm{Bcl}-2$, a single $28 \mathrm{kDa}$ band was seen; expression was high in the MCF-7 cell line and low in the SKBR3 cell line, as reported in the literature [26,42,52].

\section{Immunohistochemistry}

To account for intratumor heterogeneity, two separate sets of slides - each containing a core from a different area of the tumor for each patient - were used to evaluate the expression of each marker. Bcl-2 and Her2/neu did not have significant amounts of nuclear staining, and only the membranous/cytoplasmic compartments were analyzed, and vice versa, for ER and PR staining. Bag-1 staining was either nuclear or cytoplasmic, and many specimens had both nuclear and cytoplasmic staining. We performed log-regression analyses to assess the correlation between the two slides for Bag-1 and Bcl-2, as demonstrated in Figure 3. The matching spots on each array were highly correlated for all four markers $(R=0.6$ for Bag- 1 , $R=0.7$ for Bcl-2, $R=0.74$ for the $\mathrm{ER}, R=0.79$ for the $\mathrm{PR}$ and $R=0.92$ for Her2/neu). AQUA scores ranged from 8.3 to 146.02 for the total Bag-1 score (median, 24.07), from 8.37 to 259.61 for Bcl-2 (median, 32.04), from 2.34 to 94.097 for the PR (median, 6.58), from 1.085 to 61.164 for Her2/neu (median, 2.03), and from 2.29 to 105.39 for the ER (median, 13.46). Examples of Bag-1 and Bcl-2 staining are shown in Figure 4.

For each of the markers, the AQUA scores from both sets of slides were combined to give a single dataset. Tumor spots were deemed uninterpretable if they had insufficient tumor cells, loss of tissue in the spot or an abundance of necrotic tissue. For patients who had two interpretable histospots, a composite score was formed by taking the average of the two
Figure 2

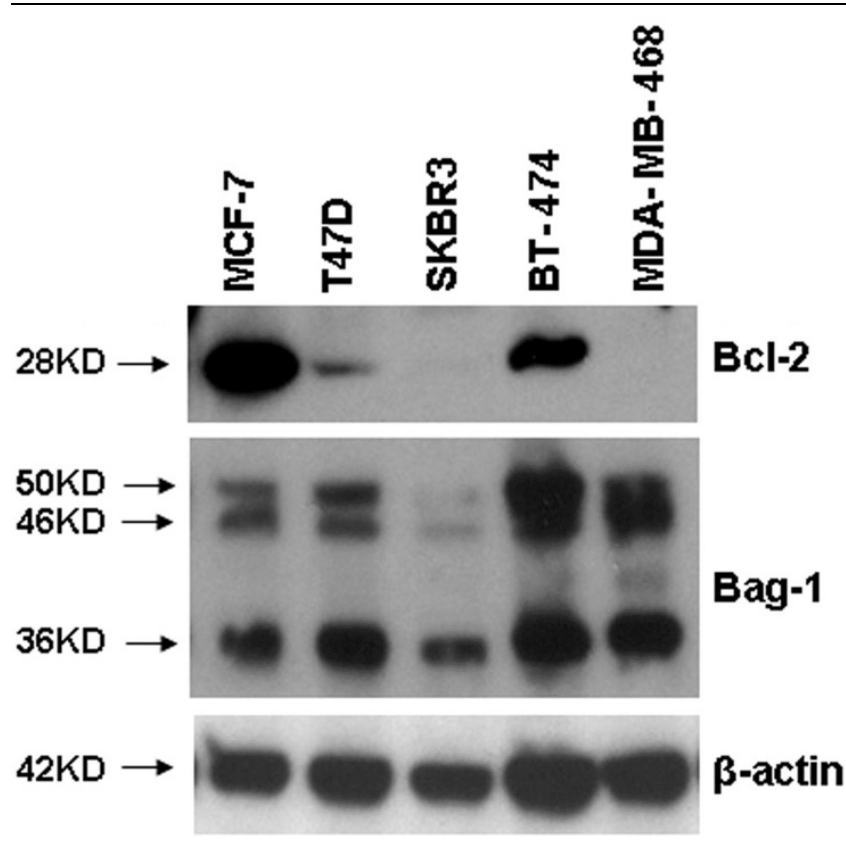

Expression of $\mathrm{Bcl}-2$ antanogene-1 isoforms and $\mathrm{Bcl}-2$. Expression of $\mathrm{Bcl}-2$ antanogene-1 (Bag-1) isoforms and $\mathrm{Bcl}-2$, using $\beta$-actin as a loading control in a panel of breast cancer cell lines.

scores. For patients with only one interpretable core, the single score was used. The combined dataset for Bag-1 had scores for 574 patients. We obtained scores for Bcl-2, Her2/ Neu, ER and PR for 528 patients, 608 patients, 601 patients and 595 patients, respectively.

Given that the nodal status often determines the standard clinical approach to patients, we assessed the prognostic value of Bag-1 and Bcl-2 in the entire cohort, as well as within the node-positive and node-negative subsets of patients. Using the Cox univariate survival analysis of raw AQUA scores, we found that Bag-1 expression (nuclear, cytoplasmic and total) was associated with breast cancer-specific survival in the node-positive subset only ( $P=0.006$ for the total Bag-1 score), whereas Bcl-2 expression was associated with survival in the entire cohort and in the node-positive subset $(P=0.008$ and $P=0.002$, respectively). The association with survival for Bag-1 and Bcl-2 within the node-positive subset (but not the node-negative subset) might be due to the larger number of events (deaths) within the node-positive subset.

Table 1 presents the associations between continuous scores of Bag-1, Bcl-2, ER, PR and Her2/neu and survival in the entire cohort and in the node-negative and node-positive subsets. There were no remarkable differences between nuclear Bag-1 scores, cytoplasmic Bag-1 scores and total Bag-1 scores as predictors of survival; the remainder of these analyses will therefore focus on the total Bag-1 scores. 
Figure 3

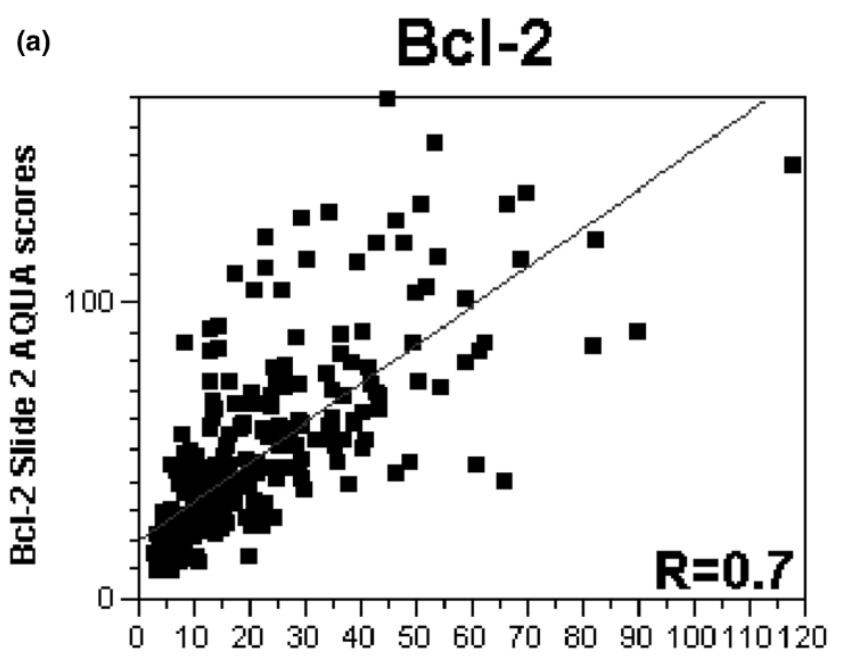

Bcl-2 Slide 1 A QUA scores

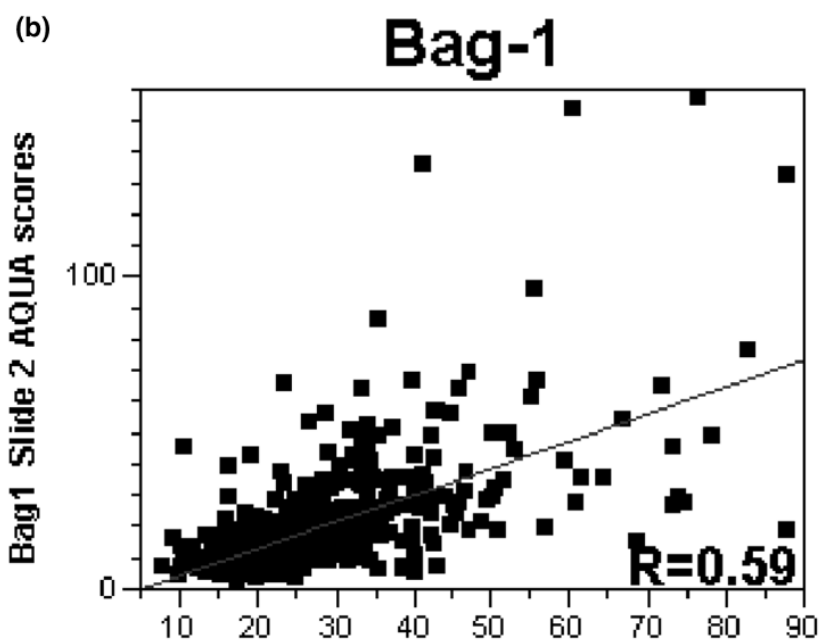

Bag1 Slide 1 AQUA scores

Regression plot for scores from breast cancer arrays stained for $\mathrm{Bcl}-2$ and $\mathrm{Bcl}-2$ antanogene-1. Regression plot for scores from the two breast cancer arrays stained for (a) Bcl-2 and (b) Bcl-2 antanogene-1 (Bag-1). AQUA, automated quantitative analysis.

Continuous AQUA scores were then dichotomized arbitrarily by the median score, reflecting the use of routine statistical divisions in the absence of an underlying justification for division of expression levels. Kaplan-Meier survival curves were generated for the total Bag-1 score and Bcl-2, as shown in Figure 5. The log-rank analysis revealed a statistically significant association with survival in the node-positive subset for Bcl-2 and Bag-1 ( $P=0.016$ for both markers), and for Bcl-2 in the entire cohort $(P=0.0042)$.

Using the Cox proportional hazards model, we performed multivariable analyses to assess the independent prognostic value of Bag-1 and Bcl-2 expression. Neither of these markers retained their independent prognostic value in this model, and the only markers to be independent predictors of survival were Her2/neu, tumor size and nodal status.

To assess the association between Bag-1 and Bcl-2 expression and other commonly used clinical and pathological parameters, we performed analyses of variance. No associations were found between expression of $\mathrm{Bag}-1$ or $\mathrm{Bcl}-2$ and nodal status, tumor size, age or nuclear grade.

For patients who had AQUA scores for all five biomarkers, we assessed the associations between biomarkers by Spearman's rho test, as demonstrated in Table 2. Bag-1 and Bcl-2 were strongly correlated with the ER, and with the PR but to a lesser degree.

Figure 1 shows a principal component biplot, in which both patient profiles and biomarker profiles are projected onto the leading principal components. As can be seen, the samples are distributed in a tree-like branch structure. The samples on the branch in the positive direction of the first principal component are associated with high Her2/neu expression levels and low to medium levels of ER, PR, Bag-1 and Bcl-2. Similarly, the samples in the upper left branch have elevated PR expression levels, low to medium ER, Bcl-2 and Bag-1 expression levels, and low Her2/neu expression levels. The samples in the lower left branch have elevated ER, Bcl-2 and Bag-1 levels, low to medium PR levels, and low Her2/neu levels. The bulk of the samples are localized next to the origin, and therefore their inner products with any of the five biomarker vectors are not high - thus indicating that these patients have median or below median expression values across all five biomarkers. Censored patients with less than 10-year follow-up time were omitted from the biplot. The figure further demonstrates the strong association between ER, Bag-1 and Bcl-2.

\section{Discussion}

In the present work we assessed expression of $\mathrm{Bcl}-2$ and Bag1 in primary breast cancer specimens. Consistent with published reports, we demonstrated that high Bcl-2 expression is associated with improved survival and ER-positive and PRpositive tumors. To the best of our knowledge, this is the first large cohort study assessing Bag-1 expression and its association with $\mathrm{Bcl}-2, \mathrm{ER}, \mathrm{PR}$ and Her2/neu, using continuous output scores, rather than arbitrary pathologist-based divisions of scores into high/low or strong/weak. We demonstrated an association between high Bag-1 expression and survival in the node-positive patients, and found that Bag-1 tends to be coexpressed with Bcl-2, ER and PR. Of the markers studied, the strongest association in expression was found between $\mathrm{Bcl}-2$ and ER. On multivariate analysis, neither Bcl-2 nor Bag-1 retained their independent prognostic value - probably due to the strong association with ER and PR expression. One prior report in the literature used a cohort of 920 patients, and showed that $\mathrm{Bcl}-2$ was an independent prognostic marker. 
(a)
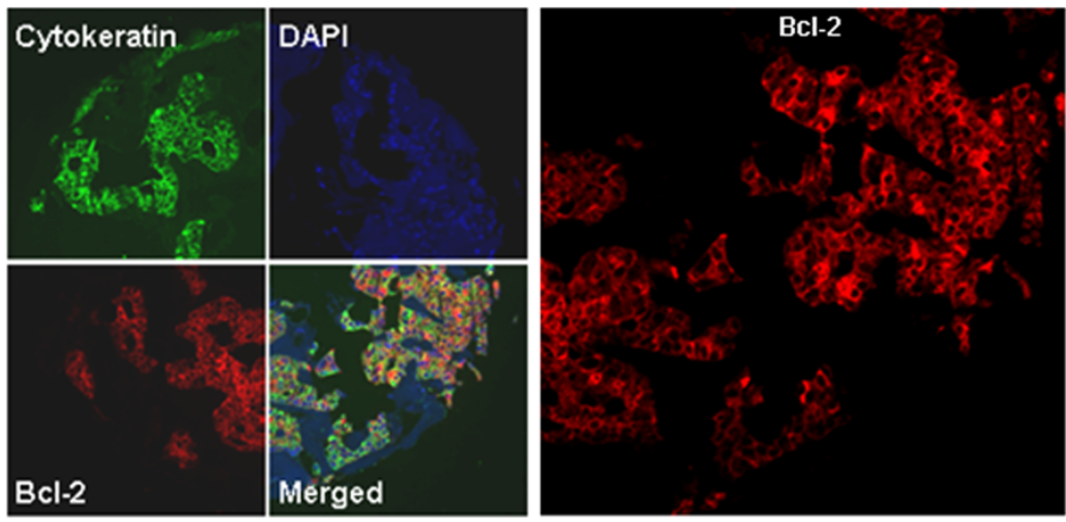

(b)
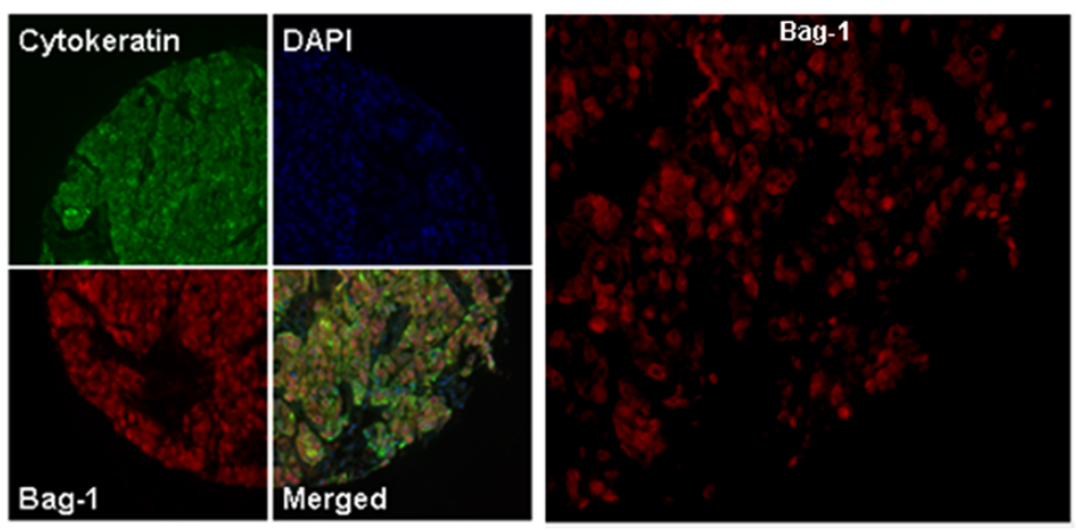

(c)
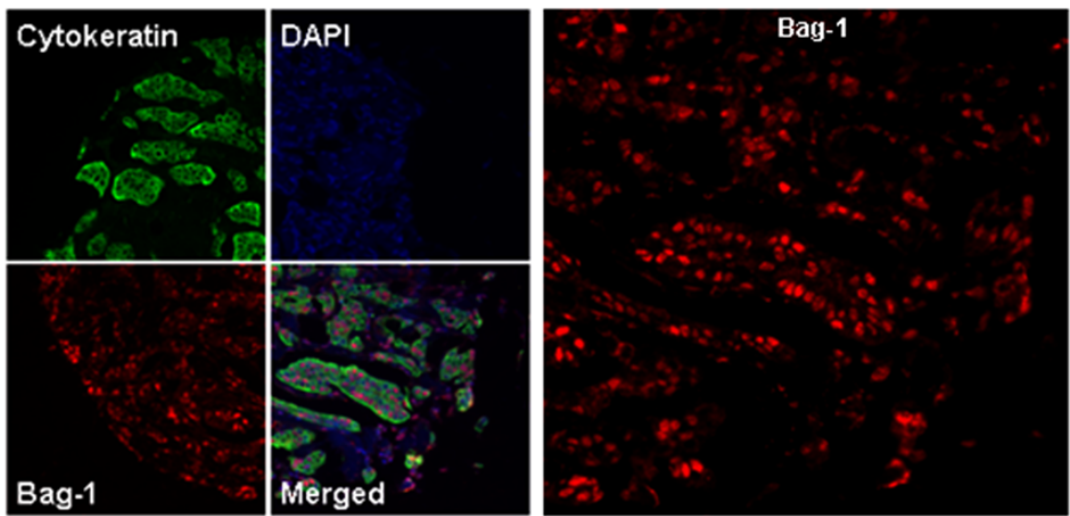

Immunoflourescent staining of Bcl-2 and Bcl-2 antanogene-1 in breast tumor tissue. (a) Cytoplasmic Bcl-2, (b) cytoplasmic and nuclear Bcl-2 antanogene-1 (Bag-1) and (c) nuclear Bag-1 staining in a breast cancer histospot - using cytokeratin to the define tumor mask, using 4',6-diamidino-2-phenylindole to define the nuclear compartment, and using Cy5 for identifying the target (Bcl-2 and Bag-1).

The smaller size of the present cohort might account for our inability to reproduce this result [6].

Staging of primary breast cancer is performed to determine prognosis and to select adjuvant therapies, which decrease the risk of relapse and death. Standard staging criteria are beneficial for discriminating between patients, but within each stage group there is variability in outcome and in biological profiles of tumors. Molecular markers such as Bcl-2 and Bag1 expression could supplement our standard staging informa- tion. Adjuvant chemotherapy decreases the risk of death by approximately $50 \%$ in node-positive patients, and the current standard of care in the United States includes relatively aggressive regimens using multiple chemotherapy agents, usually given in a dose-dense fashion [2,71]. The benefit from aggressive chemotherapy regimens for node-positive breast cancer is much lower for patients with hormone receptor-positive tumors than for those with ER/PR-negative tumors [71]. Markers of improved prognosis (such as Bag-1 and Bcl-2) in this group of patients could therefore enable us to determine 
Table 1

Association between Bcl-2 antanogene-1 (Bag-1), Bcl-2, estrogen receptor, progesterone receptor and Her2/neu and breast cancerspecific survival by Cox univariate analysis with 10-year follow-up

\begin{tabular}{|c|c|c|c|c|c|c|}
\hline Patient subset & Bag-1 (general) & Bag-1 (nuclear) & $\mathrm{Bcl}-2$ & Estrogen receptor & $\begin{array}{l}\text { Progesterone } \\
\text { receptor }\end{array}$ & Her2/neu \\
\hline Node positive & $\begin{array}{l}P=0.006, \mathrm{n}= \\
259, \mathrm{HR}=0.98 \\
(0.97 \text { to } 0.995)\end{array}$ & $\begin{array}{l}P=0.008, \mathrm{n}= \\
259, \mathrm{HR}=0.987 \\
(0.978 \text { to } 0.997)\end{array}$ & $\begin{array}{l}P=0.002, \mathrm{n}= \\
242, \mathrm{HR}=0.99 \\
(0.98 \text { to } 0.997)\end{array}$ & $\begin{array}{l}P=0.0033, \mathrm{n}= \\
270, \mathrm{HR}=0.988 \\
(0.98 \text { to } 0.996)\end{array}$ & $\begin{array}{l}P=0.0012, \mathrm{n}= \\
270, \mathrm{HR}=0.97 \\
(0.96 \text { to } 0.99)\end{array}$ & $\begin{array}{l}P=0.0091, \mathrm{n}= \\
272, \mathrm{HR}=1.02 \\
(1.006 \text { to } 1.036)\end{array}$ \\
\hline Node-negative & $\begin{array}{l}P=0.67, \mathrm{n}=259 \\
\mathrm{HR}=0.997 \\
(0.98 \text { to } 1.01)\end{array}$ & $\begin{array}{l}P=0.47, \mathrm{n}=259 \\
\mathrm{HR}=0.995 \\
(0.98 \text { to } 1.007)\end{array}$ & $\begin{array}{l}P=0.59, \mathrm{n}=240 \\
\mathrm{HR}=0.998 \\
(0.99 \text { to } 1.004)\end{array}$ & $\begin{array}{l}P=0.57, \mathrm{n}=273 \\
\mathrm{HR}=0.997 \\
(0.98 \text { to } 1.008)\end{array}$ & $\begin{array}{l}P=0.25, \mathrm{n}=266 \\
\mathrm{HR}=0.99 \\
(0.97 \text { to } 1.006)\end{array}$ & $\begin{array}{l}P=0.22, \mathrm{n}=276 \\
\mathrm{HR}=1.02 \\
(0.98 \text { to } 1.05)\end{array}$ \\
\hline All patients & $\begin{array}{l}P=0.08, \mathrm{n}=518 \\
\mathrm{HR}=0.99 \\
(0.98 \text { to } 1.001)\end{array}$ & $\begin{array}{l}P=0.06, \mathrm{n}=517 \\
\mathrm{HR}=0.99 \\
(0.985 \text { to } 1)\end{array}$ & $\begin{array}{l}P=0.008, n= \\
482, H R=0.99 \\
(0.989 \text { to } 0.999)\end{array}$ & $\begin{array}{l}P=0.01, \mathrm{n}=543 \\
\mathrm{HR}=0.99 \\
(0.984 \text { to } 0.998)\end{array}$ & $\begin{array}{l}P=0.0006, \mathrm{n}= \\
536, \mathrm{HR}=0.98 \\
(0.97 \text { to } 0.99)\end{array}$ & $\begin{array}{l}P=0.0007, \mathrm{n}= \\
548, \mathrm{HR}=1.027 \\
(1.012 \text { to } 1.04)\end{array}$ \\
\hline
\end{tabular}

Data in bold are significant $(P<0.05)$. Data in parentheses are the $95 \%$ confidence intervals. HR, hazard ratio.

which patients are cured without adjuvant chemotherapy, thus avoiding the toxicity and cost associated with chemotherapy.

The biological basis for the association between high $\mathrm{Bcl}-2$ and high Bag-1 expression and improved survival has yet to be determined. Given that both of these proteins are key antiapoptotic mediators that are part of the mitochondrial (indirect) pathway [72], one would expect their expression would be associated with decreased survival, rather than with increased survival. One plausible explanation is that poorly differentiated tumors depend on other prosurvival pathways, and decreased $\mathrm{Bcl}-2$ and Bag-1 expression is merely a marker of aggressive tumor behavior rather than mechanistically associated with aggressive biology. Breast cancer studies in the literature have consistently demonstrated an association between high $\mathrm{Bcl}-2$ expression and improved survival [4-24], and similar findings have been demonstrated in other diseases [73].

Another possible explanation for our findings is that in goodprognosis breast cancer tumors, Bcl-2 and Bag-1 have other dominant roles that are not related to their anti-apoptotic functions. For example, studies have shown that high levels of Bcl2 actually inhibit cell growth [74,75]. Most of the literature, however, supports an anti-apoptotic role of Bcl-2 and Bag-1 in early-stage breast cancer, which appears to be related to the transcriptional function of ER. Nuclear Bag-1 stimulates the activity of the $\alpha$ and $\beta$ subunits of the ER [46], and this might be the basis for coexpression of ER and Bag-1 in human tumors. The PR is a transcriptional target of the ER, and would thus similarly be expected to have coexpression with Bag-1. ER transcriptional activity results in $\mathrm{Bcl}-2$ upregulation in breast cancer, and both ER and $\mathrm{Bcl}-2$ are associated with chemotherapy resistance in breast cancer $[76,77]$. The strong association between ER, PR, Bcl-2 and Bag-1 in our study suggests that co-targeting these molecules in hormone receptor-positive breast cancer might provide greater benefit than chemotherapy, or might be a beneficial strategy for sensitizing these tumors to chemotherapy - including in the node-positive subset of patients.
Drugs that target $\mathrm{Bcl}-2$ are already in clinical trials. Antisense to Bcl-2 has activity in breast cancer in preclinical models as a single agent and also sensitizes high Bcl-2-expressing cells to a range of chemotherapeutic agents [26]. A randomized clinical trial for metastatic melanoma comparing dacarbazine alone with dacarbazine and $\mathrm{Bcl}-2$ antisense demonstrated an increase in response rates and improved survival in patients with less aggressive disease, but not in patients with more aggressive disease (as assessed by levels of lactate dehydrogenase (LDH) [78]. Unfortunately, expression of Bcl-2 was not assessed in this clinical trial; however, previous studies on metastatic melanoma specimens suggest that patients with more advanced disease have significantly lower levels of Bcl2 expression [73]. Additional small-molecule inhibitors that target $\mathrm{Bcl}-2$ are currently being studied $[79,80]$. Attempts at targeting Bag-1 as a sensitizer to chemotherapy are in their infancy [81], and our data suggest that combinations of antihormonal therapy with drugs that target Bcl-2 and/or Bag-1 should also be investigated, particularly in patients with high Bcl-2 or Bag-1 levels.

\section{Conclusion}

In summary, using an automated quantitative method of protein expression analysis to study a large cohort of primary tumors, we have shown that both Bcl-2 and Bag-1 are associated with improved survival in node-positive breast cancer, and that both $\mathrm{Bcl}-2$ and $\mathrm{Bag}-1$ are strongly associated with ER and PR expression. Targeting Bcl-2 and/or Bag-1 in nodepositive, hormone receptor-positive breast cancer might improve the therapeutic ratio of adjuvant therapy in this population. Future clinical trials using agents that target $\mathrm{Bcl}-2$ and/ or Bag-1 in breast cancer should focus on hormone receptorpositive patients, and all studies should incorporate assessment of target expression in pretreatment tumors to assess the association between target expression and response to therapy.

\section{Competing interests}

RLC and DLR are founders, stockholders, and consultants of HistoRx, a private corporation to which Yale University has 
$\mathrm{Bcl}-2$

(a)

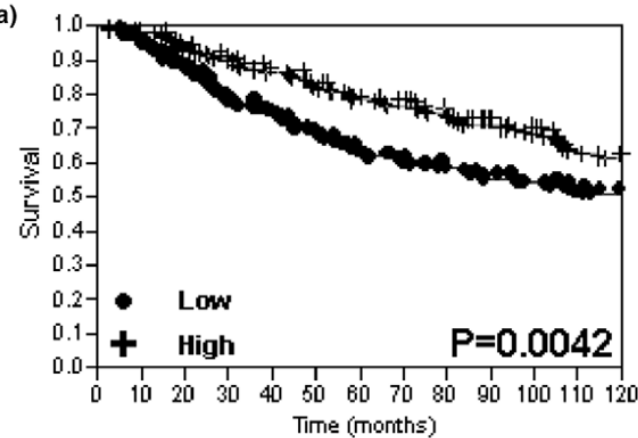

(b)

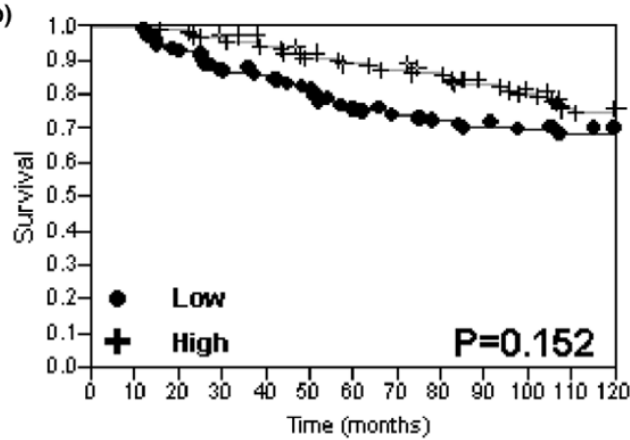

(c)

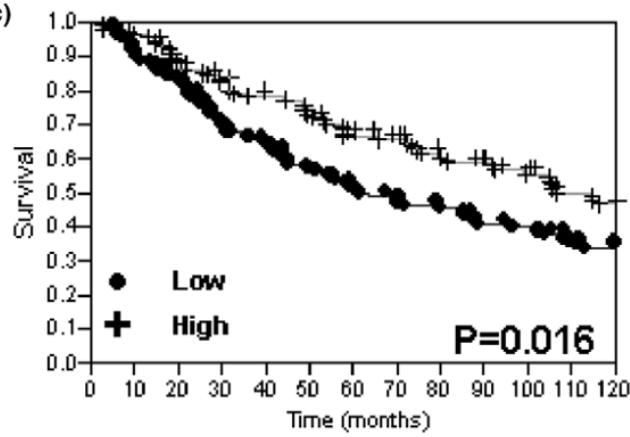

Bag1
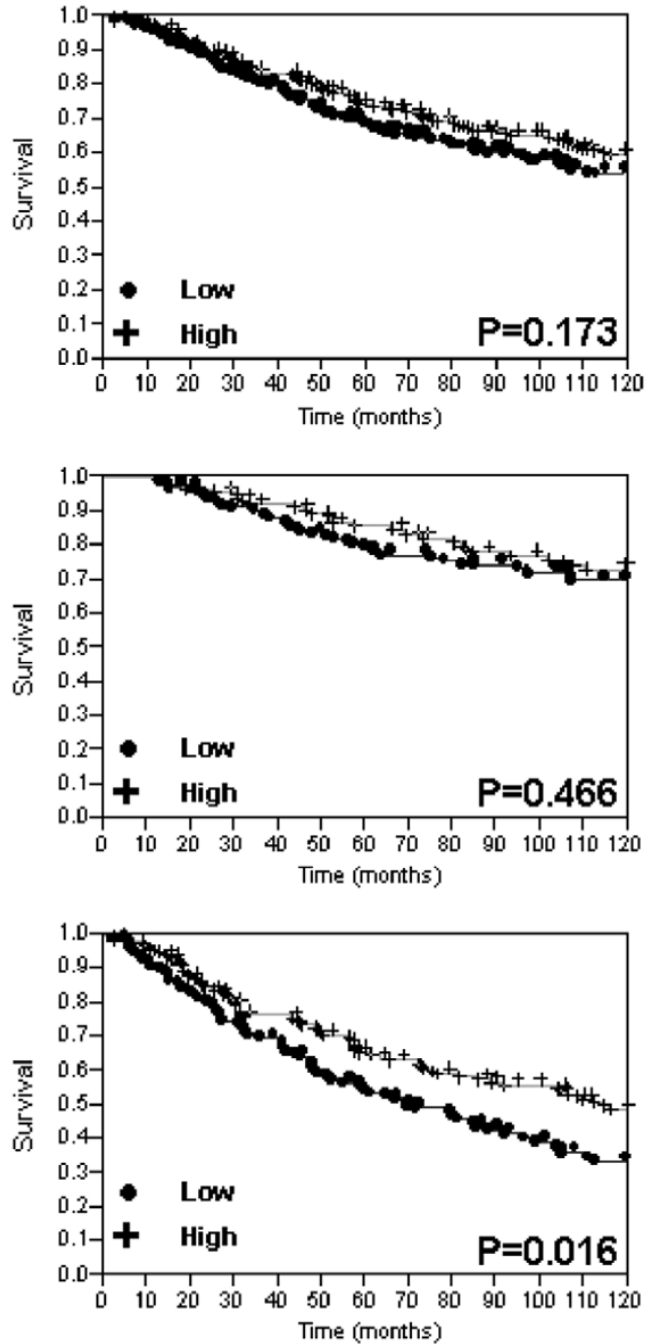

Kaplan-Meier survival curves for Bcl-2 and Bcl-2 antanogene-1. Kaplan-Meier survival curves for Bcl-2 and Bcl-2 antanogene-1 (Bag-1) automated quantitative analysis scores dichotomized by the median score for (a) the entire cohort of patients, (b) node-negative patients, and (c) nodepositive patients.

Table 2

Spearman's rho associations between expression of Her2/neu, estrogen receptor, progesterone receptor Bcl-2 antanogene-1 (Bag1) and Bcl-2

\begin{tabular}{lllll}
\hline & Estrogen receptor & Progesterone receptor & Bag-1 & Bcl-2 \\
\hline Her2/neu & $-0.0093, P=0.82(-0.0897$ & $-0.066, P=0.93(-0.146$ to & $0.0617, P=0.1430(-$ & $-0.0379, P=0.3885(-$ \\
& to 0.0712) & $0.0149)$ & 0.0209 to 0.1436$)$ & 0.1234 to 0.0482$)$ \\
Estrogen receptor & & $\begin{array}{l}0.4942, P<0.0001(0.4304 \\
\text { to 0.5531) }\end{array}$ & $\begin{array}{l}0.4150, P<0.0001(0.3438 \\
\text { to } 0.4814)\end{array}$ & $\begin{array}{l}0.5459, P<0.0001(0.4824 \\
\text { to } 0.6036)\end{array}$ \\
Progesterone receptor & & $\begin{array}{l}0.2260, P<0.0001(0.1456 \\
\text { to } 0.3035)\end{array}$ & $0.3661, P<0.0001(0.2889$ \\
& & & & $0.4385)$ \\
Bag-1 & & & $0.3050, P<0.0001(0.2228$ \\
& & & to 0.3830$)$
\end{tabular}

Data in bold are significant $(P<0.05)$. Data in parentheses represent the $95 \%$ confidence intervals. 
given exclusive rights to produce and distribute software and technologies embedded in AQUA. Yale University retains patent rights for the AQUA technology. The other authors declare that they have no competing interests.

\section{Authors' contributions}

$\mathrm{HMK}$ and $\mathrm{YK}$ contributed equally to this work. YK and HMK initiated the project, performed all the computational aspects of the projects and drafted the manuscript. YN performed the experiments for BAG-1 and Bcl-2, and assisted in drafting the manuscript. RLC and DLR developed the AQUA technology. JMG and CM performed the AQUA analysis for Her2, ER and PR. All authors read and approved the manuscript.

\section{Acknowledgements}

This work was supported by a grant from the Susan G. Komen Foundation (to YK). HMK is supported by the Susan G. Komen Foundation and the Breast Cancer Alliance.

\section{References}

1. Jemal A, Siegel R, Ward E, Murray T, Xu J, Thun MJ: Cancer statistics, 2007. CA Cancer J Clin 2007, 57:43-66.

2. Citron ML, Berry DA, Cirrincione C, Hudis C, Winer EP, Gradishar WJ, Davidson NE, Martino S, Livingston R, Ingle JN, Perez EA, Carpenter J, Hurd D, Holland JF, Smith BL, Sartor Cl, Leung EH, Abrams J, Schilsky RL, Muss HB, Norton L: Randomized trial of dose-dense versus conventionally scheduled and sequential versus concurrent combination chemotherapy as postoperative adjuvant treatment of node-positive primary breast cancer: first report of Intergroup Trial C9741/Cancer and Leukemia Group B Trial 9741. J Clin Oncol 2003, 21:1431-1439.

3. Fisher B, Redmond C, Legault-Poisson S, Dimitrov NV, Brown AM, Wickerham DL, Wolmark N, Margolese RG, Bowman D, Glass AG: Postoperative chemotherapy and tamoxifen compared with tamoxifen alone in the treatment of positive-node breast cancer patients aged $\mathbf{5 0}$ years and older with tumors responsive to tamoxifen: results from the National Surgical Adjuvant Breast and Bowel Project B-16. J Clin Oncol 1990, 8:1005-1018.

4. Bilalovic N, Vranic S, Hasanagic S, Basic H, Tatarevic A, Beslija S, Selak I: The $\mathrm{Bcl}-2$ protein: a prognostic indicator strongly related to ER and PR in breast cancer. Bosn J Basic Med Sci 2004, 4:5-12.

5. Binder C, Marx D, Overhoff R, Binder L, Schauer A, Hiddemann W: $\mathrm{Bcl}-2$ protein expression in breast cancer in relation to established prognostic factors and other clinicopathological variables. Ann Oncol 1995, 6:1005-1010.

6. Callagy GM, Pharoah PD, Pinder SE, Hsu FD, Nielsen TO, Ragaz $\mathrm{J}$, Ellis $\mathrm{IO}$, Huntsman $\mathrm{D}$, Caldas $\mathrm{C}$ : $\mathbf{B c l}-2$ is a prognostic marker in breast cancer independently of the Nottingham Prognostic Index. Clin Cancer Res 2006, 12:2468-2475.

7. Dimitrakakis C, Konstadoulakis M, Messaris E, Kymionis G, Karayannis M, Panoussopoulos D, Michalas S, Androulakis G: Molecular markers in breast cancer: can we use c-erbB-2, p53, bcl-2 and bax gene expression as prognostic factors? Breast 2002, 11:279-285.

8. Gaballah HE, Abdel Salam I, Abdel Wahab N, Mansour OM: Plasma bcl-2 and nitric oxide: possible prognostic role in patients with metastatic breast cancer. Med Oncol 2001, 18:171-178.

9. Gee JM, Robertson JF, Ellis IO, Willsher P, McClelland RA, Hoyle HB, Kyme SR, Finlay P, Blamey RW, Nicholson RI: Immunocytochemical localization of BCL-2 protein in human breast cancers and its relationship to a series of prognostic markers and response to endocrine therapy. Int J Cancer 1994, 59:619-628.

10. Hellemans $P$, van Dam PA, Weyler J, van Oosterom AT, Buytaert $\mathrm{P}$, Van Marck E: Prognostic value of bcl-2 expression in invasive breast cancer. Br J Cancer 1995, 72:354-360.
11. Jansen RL, Joosten-Achjanie SR, Volovics A, Arends JW, Hupperets PS, Hillen HF, Schouten HC: Relevance of the expression of bcl-2 in combination with p53 as a prognostic factor in breast cancer. Anticancer Res 1998, 18:4455-4462.

12. Kapranos N, Karaiosifidi H, Valavanis C, Kouri E, Vasilaros S: Prognostic significance of apoptosis related proteins $\mathrm{Bcl}-2$ and Bax in node-negative breast cancer patients. Anticancer Res 1997, 17:2499-2505.

13. Lee KH, Im SA, Oh DY, Lee SH, Chie EK, Han W, Kim DW, Kim TY, Park IA, Noh DY, Heo DS, Ha SW, Bang YJ: Prognostic significance of bcl-2 expression in stage III breast cancer patients who had received doxorubicin and cyclophosphamide followed by paclitaxel as adjuvant chemotherapy. BMC Cancer 2007, 12():7-63.

14. Linjawi A, Kontogiannea M, Halwani F, Edwardes M, Meterissian S: Prognostic significance of p53, bcl-2, and Bax expression in early breast cancer. J Am Coll Surg 2004, 198:83-90.

15. Malamou-Mitsi V, Gogas H, Dafni U, Bourli A, Fillipidis T, Sotiropoulou M, Vlachodimitropoulos D, Papadopoulos S, Tzaida O, Kafiri G, Kyriakou V, Markaki S, Papaspyrou I, Karagianni E, Pavlakis K, Toliou T, Scopa C, Papakostas P, Bafaloukos D, Christodoulou C, Fountzilas G: Evaluation of the prognostic and predictive value of p53 and $\mathrm{Bcl}-2$ in breast cancer patients participating in a randomized study with dose-dense sequential adjuvant chemotherapy. Ann Oncol 2006, 17:1504-1511.

16. Mauri FA, Maisonneuve $P$, Caffo O, Veronese $S$, Aldovini D, Ferrero S, Cozzaglio F, Dalla Palma P, Galligioni E, Barbareschi M: Prognostic value of estrogen receptor status can be improved by combined evaluation of $\mathrm{p} 53, \mathrm{Bcl} 2$ and $\mathrm{PgR}$ expression: an immunohistochemical study on breast carcinoma with longterm follow-up. Int J Oncol 1999, 15:1137-1147.

17. McLaughlin R, O'Hanlon D, McHale T, Connolly CE, Given HF: Prognostic implications of p53 and bcl-2 expression in 108 women with stage two breast cancer. Ir J Med Sci 2001, 170:11-13.

18. Silvestrini R, Veneroni S, Daidone MG, Benini E, Boracchi P, Mezzetti M, Di Fronzo G, Rilke F, Veronesi U: The Bcl-2 protein: a prognostic indicator strongly related to p53 protein in lymph node-negative breast cancer patients. J Nat/ Cancer Inst 1994, 86:499-504.

19. Sirvent JJ, Aguilar MC, Olona M, Pelegri A, Blazquez S, Gutierrez C: Prognostic value of apoptosis in breast cancer (pT1-pT2). A TUNEL, p53, bcl-2, bag-1 and Bax immunohistochemical study. Histol Histopathol 2004, 19:759-770.

20. Thomadaki H, Talieri M, Scorilas A: Prognostic value of the apoptosis related genes BCL2 and BCL2L12 in breast cancer. Cancer Lett 2007, 247:48-55.

21. Trere D, Montanaro L, Ceccarelli C, Barbieri S, Cavrini G, Santini $D$, Taffurelli M, Derenzini M: Prognostic relevance of a novel semiquantitative classification of $\mathrm{Bcl} 2$ immunohistochemical expression in human infiltrating ductal carcinomas of the breast. Ann Oncol 2007, 18:1004-1014.

22. van Slooten HJ, Clahsen PC, van Dierendonck JH, Duval C, Pallud C, Mandard AM, Delobelle-Deroide A, Velde CJ van de, Vijver MJ van de: Expression of $\mathrm{Bcl}-2$ in node-negative breast cancer is associated with various prognostic factors, but does not predict response to one course of perioperative chemotherapy. Br J Cancer 1996, 74:78-85.

23. Yang $Q$, Sakurai T, Yoshimura G, Suzuma T, Umemura T, Nakamura M, Nakamura Y, Mori I, Kakudo K: Prognostic value of Bcl2 in invasive breast cancer receiving chemotherapy and endocrine therapy. Oncol Rep 2003, 10:121-125.

24. Zhang GJ, Tsuda H, Adachi I, Fukutomi T, Yamamoto H, Hirohashi $\mathrm{S}$ : Prognostic indicators for breast cancer patients with one to three regional lymph node metastases, with special reference to alterations in expression levels of bcl-2, p53 and c-erbB-2 proteins. Jpn J Clin Oncol 1997, 27:371-377.

25. Adams JM, Cory S: The Bcl-2 protein family: arbiters of cell survival. Science 1998, 281:1322-1326.

26. Emi M, Kim R, Tanabe K, Uchida $Y$, Toge $T$ : Targeted therapy against $\mathrm{Bcl}-2$-related proteins in breast cancer cells. Breast Cancer Res 2005, 7:R940-R952.

27. Bhargava V, Kell DL, Rijn M van de, Warnke RA: Bcl-2 immunoreactivity in breast carcinoma correlates with hormone receptor positivity. Am J Pathol 1994, 145:535-540.

28. Doglioni C, Dei Tos AP, Laurino L, Chiarelli C, Barbareschi M, Viale $\mathrm{G}$ : The prevalence of $\mathrm{BCL}-2$ immunoreactivity in breast carci- 
nomas and its clinicopathological correlates, with particular reference to oestrogen receptor status. Virchows Arch 1994, 424:47-51.

29. Lee WY, Jin YT, Tzeng CC: Reciprocal expression of Bcl-2 and p53 in breast ductal carcinoma. Anticancer Res 1996, 16:3007-3012.

30. Sierra A, Lloveras B, Castellsague X, Moreno L, Garcia-Ramirez M, Fabra A: Bcl-2 expression is associated with lymph node metastasis in human ductal breast carcinoma. Int $J$ Cancer 1995, 60:54-60.

31. Charpin C, Garcia S, Bouvier C, Devictor B, Andrac L, Lavaut MN, Allasia C: Automated and quantitative immunocytochemical assays of $\mathrm{Bcl}-2$ protein in breast carcinomas. $\mathrm{Br} J$ Cancer 1997, 76:340-346.

32. Diaz-Cano SJ, Garcia-Moliner M, Carney W, Wolfe HJ: Bcl-2 expression and DNA fragmentation in breast carcinoma, pathologic and steroid hormone receptors correlates. Diagn Mol Pathol 1997, 6:199-208.

33. Lee HD, Koo JY, Jung WH: Correlations of bcl-2 expression with clinicopathological features in breast cancer. Yonsei Med J 1997, 38:206-211.

34. Berardo MD, Elledge RM, de Moor C, Clark GM, Osborne CK, Allred DC: bcl-2 and apoptosis in lymph node positive breast carcinoma. Cancer 1998, 82:1296-1302.

35. Magro G, Bisceglia M, Michal M: Expression of steroid hormone receptors, their regulated proteins, and bcl-2 protein in myofibroblastoma of the breast. Histopathology 2000, 36:515-521.

36. Kymionis GD, Dimitrakakis CE, Konstadoulakis MM, Arzimanoglou I, Leandros E, Chalkiadakis G, Keramopoulos A, Michalas S: Can expression of apoptosis genes, bcl-2 and bax, predict survival and responsiveness to chemotherapy in node-negative breast cancer patients? J Surg Res 2001, 99:161-168.

37. Martinez-Arribas F, Nunez-Villar MJ, Lucas AR, Sanchez J, Tejerina $\mathrm{A}$, Schneider J: Immunofluorometric study of $\mathrm{Bcl}-2$ and $\mathrm{Bax}$ expression in clinical fresh tumor samples from breast cancer patients. Anticancer Res 2003, 23:565-568.

38. Martinez-Arribas F, Alvarez T, Del Val G, Martin-Garabato E, Nunez-Villar MJ, Lucas R, Sanchez J, Tejerina A, Schneider J: Bcl2 expression in breast cancer: a comparative study at the mRNA and protein level. Anticancer Res 2007, 27:219-222.

39. Kumaravel B, Arihiro K, Kaneko M, Fujii S, Inai K: Expression of bcl-2 protein in breast carcinoma with correlation to expression of p53 protein and clinicopathological factors. Breast Cancer 1996, 3:173-179.

40. O'Driscoll L, Linehan R, S MK, Cronin D, Purcell R, Glynn S, E WM, $\mathrm{A} \mathrm{DH}, \mathrm{N} \mathrm{JOH}$, Parkinson M, Clynes M: Lack of prognostic significance of survivin, survivin-deltaEx3, survivin-2B, galectin-3, bag-1, bax-alpha and MRP-1 mRNAs in breast cancer. Cancer Lett 2003, 201:225-236.

41. Kroger N, Milde-Langosch K, Riethdorf S, Schmoor C, Schumacher M, Zander AR, Loning T: Prognostic and predictive effects of immunohistochemical factors in high-risk primary breast cancer patients. Clin Cancer Res 2006, 12:159-168.

42. Yang $X$, Hao $Y$, Ding Z, Pater A, Tang SC: Differential expression of antiapoptotic gene BAG-1 in human breast normal and cancer cell lines and tissues. Clin Cancer Res 1999, 5:1816-1822.

43. Takayama S, Sato T, Krajewski S, Kochel K, Irie S, Millan JA, Reed JC: Cloning and functional analysis of BAG-1: a novel Bcl-2binding protein with anti-cell death activity. Cell 1995, 80:279-284

44. Bardelli A, Longati $P$, Albero D, Goruppi S, Schneider C, Ponzetto C, Comoglio PM: HGF receptor associates with the anti-apoptotic protein BAG-1 and prevents cell death. Embo J 1996, 15:6205-6212.

45. Takayama S, Reed JC: Molecular chaperone targeting and regulation by BAG family proteins. Nat Cell Biol 2001, 3:E237-E241.

46. Cutress RI, Townsend PA, Sharp A, Maison A, Wood L, Lee R, Brimmell M, Mullee MA, Johnson PW, Royle GT, Bateman AC, Packham G: The nuclear BAG-1 isoform, BAG-1L, enhances oestrogen-dependent transcription. Oncogene 2003, 22:4973-4982.

47. Townsend PA, Stephanou A, Packham G, Latchman DS: BAG-1: a multi-functional pro-survival molecule. Int J Biochem Cell Biol 2005, 37:251-259.

48. Tang SC: BAG-1, an anti-apoptotic tumour marker. IUBMB Life 2002, 53:99-105.
49. Yang $X$, Chernenko G, Hao $Y$, Ding Z, Pater MM, Pater A, Tang SC: Human BAG-1/RAP46 protein is generated as four isoforms by alternative translation initiation and overexpressed in cancer cells. Oncogene 1998, 17:981-989.

50. Packham G, Brimmell M, Cleveland JL: Mammalian cells express two differently localized Bag-1 isoforms generated by alternative translation initiation. Biochem J 1997, 328(Pt 3):807-813.

51. Coldwell MJ, deSchoolmeester ML, Fraser GA, Pickering BM, Packham G, Willis AE: The p36 isoform of BAG-1 is translated by internal ribosome entry following heat shock. Oncogene 2001, 20:4095-4100.

52. Brimmell M, Burns JS, Munson $P$, McDonald L, O'Hare MJ, Lakhani SR, Packham G: High level expression of differentially localized BAG-1 isoforms in some oestrogen receptor-positive human breast cancers. Br J Cancer 1999, 81:1042-1051.

53. Cutress RI, Townsend PA, Bateman AC, Johnson PW, Ryder K, Barnes DM, Packham G: BAG-1 immunostaining and survival in early breast cancer. J Clin Oncol 2001, 19:3706-3707.

54. Krajewski S, Krajewska M, Turner BC, Pratt C, Howard B, Zapata $\mathrm{JM}$, Frenkel V, Robertson S, lonov Y, Yamamoto H, Perucho M, Takayama S, Reed JC: Prognostic significance of apoptosis regulators in breast cancer. Endocr Relat Cancer 1999, 6:29-40.

55. Pusztai L, Krishnamurti S, Perez Cardona J, Sneige N, Esteva FJ, Volchenok M, Breitenfelder P, Kau SW, Takayama S, Krajewski S, Reed JC, Bast RC Jr, Hortobagyi GN: Expression of BAG-1 and BcL-2 proteins before and after neoadjuvant chemotherapy of locally advanced breast cancer. Cancer Invest 2004, 22:248-256.

56. Sjostrom J, Blomqvist $\mathrm{C}$, von Boguslawski K, Bengtsson NO, Mjaaland I, Malmstrom P, Ostenstadt B, Wist E, Valvere V, Takayama S, Reed JC, Saksela E: The predictive value of bcl-2, bax, bcl-xL, bag-1, fas, and fas $L$ for chemotherapy response in advanced breast cancer. Clin Cancer Res 2002, 8:811-816.

57. Tang SC, Beck J, Murphy S, Chernenko G, Robb D, Watson $P$, Khalifa M: BAG-1 expression correlates with Bcl-2, p53, differentiation, estrogen and progesterone receptors in invasive breast carcinoma. Breast Cancer Res Treat 2004, 84:203-213.

58. Tang SC, Shehata N, Chernenko G, Khalifa M, Wang X: Expression of BAG-1 in invasive breast carcinomas. J Clin Oncol 1999, 17:1710-1719.

59. Townsend PA, Dublin E, Hart IR, Kao RH, Hanby AM, Cutress RI Poulsom R, Ryder K, Barnes DM, Packham G: BAG-i expression in human breast cancer: interrelationship between BAG-1 RNA, protein, HSC70 expression and clinico-pathological data. J Pathol 2002, 197:51-59.

60. Turner BC, Krajewski S, Krajewska M, Takayama S, Gumbs AA, Carter D, Rebbeck TR, Haffty BG, Reed JC: BAG-1: a novel biomarker predicting long-term survival in early-stage breast cancer. J Clin Oncol 2001, 19:992-1000.

61. Townsend PA, Cutress RI, Sharp A, Brimmell M, Packham G: BAG-1 prevents stress-induced long-term growth inhibition in breast cancer cells via a chaperone-dependent pathway. Cancer Res 2003, 63:4150-4157.

62. Kudoh M, Knee DA, Takayama S, Reed JC: Bag1 proteins regulate growth and survival of ZR-75-1 human breast cancer cells. Cancer Res 2002, 62:1904-1909.

63. Zapata JM, Krajewska M, Krajewski S, Huang RP, Takayama S, Wang HG, Adamson E, Reed JC: Expression of multiple apoptosis-regulatory genes in human breast cancer cell lines and primary tumors. Breast Cancer Res Treat 1998, 47:1 29-140.

64. Camp RL, Dolled-Filhart M, King BL, Rimm DL: Quantitative analysis of breast cancer tissue microarrays shows that both high and normal levels of HER2 expression are associated with poor outcome. Cancer Res 2003, 63:1445-1448.

65. Dolled-Filhart M, McCabe A, Giltnane J, Cregger M, Camp RL, Rimm DL: Quantitative in situ analysis of beta-catenin expression in breast cancer shows decreased expression is associated with poor outcome. Cancer Res 2006, 66:5487-5494.

66. McCabe A, Dolled-Filhart M, Camp RL, Rimm DL: Automated quantitative analysis (AQUA) of in situ protein expression, antibody concentration, and prognosis. I Natl Cancer Inst 2005, 97:1808-1815

67. Kluger HM, Dolled-Filhart M, Rodov S, Kacinski BM, Camp RL, Rimm DL: Macrophage colony-stimulating factor-1 receptor expression is associated with poor outcome in breast cancer 
by large cohort tissue microarray analysis. Clin Cancer Res 2004, 10(1 Pt 1):173-177.

68. Camp RL, Chung GG, Rimm DL: Automated subcellular localization and quantification of protein expression in tissue microarrays. Nat Med 2002, 8:1323-1327.

69. Kluger Y, Tuck DP, Chang JT, Nakayama Y, Poddar R, Kohya N, Lian Z, Ben Nasr A, Halaban HR, Krause DS, Zhang X, Newburger $\mathrm{PE}$, Weissman SM: Lineage specificity of gene expression patterns. Proc Natl Acad Sci USA 2004, 101:6508-6513.

70. Cox TFC, Cox AA: Multidimensional Scaling London: Chapman \& Hall; 2001.

71. Berry DA, Cirrincione C, Henderson IC, Citron ML, Budman DR, Goldstein LJ, Martino S, Perez EA, Muss HB, Norton L, Hudis C, Winer EP: Estrogen-receptor status and outcomes of modern chemotherapy for patients with node-positive breast cancer. JAMA 2006, 295:1658-1667.

72. Hengartner MO: The biochemistry of apoptosis. Nature 2000, 407:770-776.

73. Divito KA, Berger AJ, Camp RL, Dolled-Filhart M, Rimm DL, Kluger $\mathrm{HM}$ : Automated quantitative analysis of tissue microarrays reveals an association between high $\mathrm{Bcl}-2$ expression and improved outcome in melanoma. Cancer Res 2004, 64:8773-8777.

74. Pietenpol JA, Papadopoulos N, Markowitz S, Willson JK, Kinzler $\mathrm{KW}$, Vogelstein B: Paradoxical inhibition of solid tumor cell growth by bcl2. Cancer Res 1994, 54:3714-3717.

75. Knowlton K, Mancini M, Creason S, Morales C, Hockenbery D, Anderson BO: Bcl-2 slows in vitro breast cancer growth despite its antiapoptotic effect. J Surg Res 1998, 76:22-26.

76. Teixeira C, Reed JC, Pratt MA: Estrogen promotes chemotherapeutic drug resistance by a mechanism involving $\mathrm{Bcl}-2$ protooncogene expression in human breast cancer cells. Cancer Res 1995, 55:3902-3907.

77. Daidone MG, Luisi A, Veneroni S, Benini E, Silvestrini R: Clinical studies of $\mathrm{Bcl}-2$ and treatment benefit in breast cancer patients. Endocr Relat Cancer 1999, 6:61-68.

78. Bedikian AY, Millward M, Pehamberger H, Conry R, Gore M, Trefzer U, Pavlick AC, DeConti R, Hersh EM, Hersey P, Kirkwood JM, Haluska FG: Bcl-2 antisense (oblimersen sodium) plus dacarbazine in patients with advanced melanoma: the Oblimersen Melanoma Study Group. J Clin Oncol 2006, 24:4738-4745.

79. Mohammad RM, Wang S, Aboukameel A, Chen B, Wu X, Chen J, Al-Katib A: Preclinical studies of a nonpeptidic small-molecule inhibitor of $\mathrm{Bcl}-2$ and $\mathrm{Bcl}-\mathrm{X}(\mathrm{L})$ [(-)-gossypol] against diffuse large cell lymphoma. Mol Cancer Ther 2005, 4:13-21.

80. Li J, Viallet J, Haura EB: A small molecule pan-Bcl-2 family inhibitor, GX15-070, induces apoptosis and enhances cisplatininduced apoptosis in non-small cell lung cancer cells. Cancer Chemother Pharmacol 2008, 61:525-534.

81. Xiong J, Chen J, Chernenko G, Beck J, Liu H, Pater A, Tang SC: Antisense BAG-1 sensitizes HeLa cells to apoptosis by multiple pathways. Biochem Biophys Res Commun 2003, 312:585-591. 